Jurnal IImiah Iqra'

2541-2108 [Online] 1693-5705 [Print]

Tersedia online di: http://journal.iain-manado.ac.id/index.php/JII

\title{
Implementasi Model Pembelajaran Project Based Learning Untuk Meningkatkan Keaktifan Belajar Siswa Pada Mata Pelajaran Al Qur'an dan Hadis
}

\author{
Mohamad Syakur Rahman \\ Fakultas Tarbiyah dan IImu Keguruan IAIN Manado. \\ syakurrahman@iain-manado.ac.id \\ Ervita Kairupan \\ Fakultas Tarbiyah dan IImu Keguruan IAIN Manado \\ Ervitakairupan92@gmail.com
}

\begin{abstract}
Abstrak
Penelitian ini berjudul Implementasi Model Pembelajaran Project Based Learning untuk meningkatkan keaktifan belajar siswa pada mata pelajaran Al Qur'an Hadis di MTs Al-Inayah Kota Manado. Adapun rumusan masalah dalam penelitian ini adalah: (1) Bagaimana penerapan model pembelajaran di MTs Al-Inayah Manado? (2) Bagaimana implementasi model pembelajaran Project Based Learning untuk meningkatkan keaktifan belajar siswa di MTs Al-Inayah Manado? (3) Bagaimana kendala dan solusi dalam penerapan model pembelajaran Project Based Learning di MTs Al-Inayah Manado?

Penelitan ini merupakan hasil Penelitian Tindakan Kelas (Classroom Action Research). Subjek dari penelitian ini adalah siswa kelas VIII semester genap tahun akademik 2017/2018 yang berjumlah 20 siswa di MTs Al-Inayah Manado. Penelitian ini dilakukan dalam dua siklus, yang terdiri dari empat tahap yaitu: perencanaan, tindakan, observasi/pengamatan, dan refleksi. Dan setiap akhir siklus dilakukan evaluasi hasil belajar siswa. Teknik analisis dan pengumpulan data dalam penelitian ini menggunakan tes tulisan dilihat dari ketuntasan hasil belajar, lembar observasi dan dokumentasi.

Dari hasil pengamatan diperoleh kondisi kelas yang akan diteliti sebelum diberi tindakan dengan model pembelajaran Project Based Learning, yaitu keaktifan belajar siswa di MTs Al-Inayah Manado Semester II Tahun Pelajaran 2017/2018 khususnya pada mata pelajaran Al Qur'an Hadis masih sangat rendah atau dapat dikatakan motivasi siswa kurang. Hal ini disebabkan oleh guru yang masih menggunakan
\end{abstract}


pendekatan tradisional dan monoton yaitu penggunaan metode ceramah, dan pemberian tugas menulis kepada para siswanya. Pada hasil penelitian pra tindakan terlihat hanya 2 atau 10\% siswa yang mencapai kriteria ketuntasan belajar dengan nilai rata-rata 56 , dengan jumlah nilai 1120. Maka hasil ini masih pada kategori sangat rendah. Setelah diterapkannya model pembelajaran Project Based Learning pada mata pelajaran Al Qur'an Hadis, keaktifan siswa sudah mulai baik dari observasi awal yang hanya menggunakan metode ceramah, di mana siswa sudah lebih aktif bertanya, menjawab dan menjelaskan materi yang telah disampaikan.

Kata kunci: Model Pembelajaran; Project Based Learning.

\begin{abstract}
This study is entitled Implementation of Project Based Learning Learning Model to improve student learning activeness in the subjects of the Qur'an Al Hadith in MTs Al-Inayah, Manado City. The formulation of the problem in this study are: (1) How is the application of learning models in MTs Al-Inayah Manado? (2) How is the implementation of the Project Based Learning learning model to improve student learning activities in MTs Al-Inayah Manado? (3) What are the constraints and solutions in applying the Project Based Learning learning model in MTs Al-Inayah Manado?

This research is the result of Classroom Action Research. The subjects of this study were students of class VIII even semester 2017/2018 academic year totaling 20 students at MTs Al-Inayah Manado. This research was conducted in two cycles, which consisted of four stages: planning, action, observation, and reflection. And at the end of each cycle an evaluation of student learning outcomes is carried out. Analysis and data collection techniques in this study used a written test seen from the completeness of learning outcomes, observation sheets and documentation.

From the observations obtained class conditions that will be examined before being given action with the Project Based Learning learning model, namely student learning activeness in MTs Al-Inayah Manado Semester II 2017/2018 Academic Year especially in the Qur'anic Hadith subjects are still very low or can be it is said that student motivation is lacking. This is caused by teachers who are still using the traditional and monotonous approach, namely the use of lecture methods, and giving writing assignments to their students. In the pre-action research results it was seen that only 2 or $10 \%$ of students reached the mastery learning criteria with an average grade of 56 , with a total score of 1120 . Then these results were still in the very low category. After applying the Project Based Learning learning model to the Qur'anic subjects of Hadith, student activity has begun both from the initial observation using only the lecture method, where students have been more active in asking questions, answering and explaining the material that has been delivered.
\end{abstract}

Keywords: Learning Model; Project Based Learning 


\section{Pendahuluan}

Manusia sejak lahir ke dunia telah memperoleh pendidikan, kasih sayang dan pendidikan dari orang tua (informal), sampai beradaptasi dilingkungan masyarakat (nonformal) hingga masuk ke bangku sekolah (formal). Kata pendidikanpun sudah tak asing lagi ditelinga, karena semua manusia yang hidup tentu memerlukan pendidikan, supaya arah hidupnya terwujud serta bisa melenyapkan kebodohan.

Menurut Kamus Besar Bahasa Indonesia (KBBI), Pendidikan berasal dari kata didik yang artinya memelihara, memberi latihan (ajaran, tuntunan, pimpinan) mengenai akhlak dan kecerdasan pikiran. Sedangkan arti kata pendidikan adalah proses pengubahan sikap dan tata laku seseorang atau kelompok orang dalam usaha mendewasakan manusia melalui upaya pengajaran dan pelatihan (Bahasa, 2005).

Menurut Peraturan Pemerintah nomor 19 tahun 2005 tentang Standar Nasional Pendidikan pada pasal 19 disebutkan proses pembelajaran pada satuan pendidikan diselenggarakan secara interaktif, inspiratif, menyenangkan, menantang, memotivasi peserta didik untuk berpartisipasi aktif, serta memberikan ruang yang cukup bagi prakasa, kreativitas, dan kemandirian sesuai bakat, minat dan pengembangan fisik serta psikologis peserta didik. Hal tersebut menyangkut tentang standar proses dari satuan pendidikan di Indonesia dengan kurikulum terbaru menggunakan kurikulum 2013 (K13), yang menekankan proses pembelajaran berpusat pada siswa dan guru hanya sebagai fasilitator.

Pembelajaran aktif secara sederhana didefinisikan sebagai metode pengajaran yang melibatkan siswa secara aktif dalam proses pembelajaran. Pembelajaran aktif mengkondisikan agar siswa selalu melakukan pengalaman belajar yang bermakna dan senantiasa berpikir tentang apa yang dapat dilakukannya selama pembelajaran.

Allah swt berfirman dalam QS. Al-Hajj/22: 46

"Maka apakah mereka tidak berjalan di muka bumi, lalu dengan hati yang mereka punyai itu mereka dapat memahami (hikmahnya) atau dengan telinga yang mereka punyai itu dapat mendengar (kisah nasib orang-or ang terdahulu) yang dengan itu mereka mendengar peringatan? Karena sesungguhnya bukanlah mata itu yang buta, tetapi yang buta ialah hati yang di dalam dada" (Agama, 2012). 
Penjelasan umum ayat di atas adalah bahwa kita diperintahkan agar mengambil pelajaran dari puing-puing peninggalan umat-umat terdahulu yang dibinasakan oleh Allah swt karena mereka telah melakukan kedurhakaan kepada Allah swt., lalu melakukan kontemplasi (perenungan) secara mendalam dengan akal, memikirkannya dan mengambil pelajaran (ibrah), nasehat dan menyimaknya penuh perhatian. Karena sesungguhnya yang buta itu bukan penglihatannya akan tetapi hatinya yang buta terhadap kebenaran dan dalam mengambil pelajaran (Basyir, Haidar, Muslim, \& Isma'il, n.d.).

Adapun ayat tersebut berkaitan dengan beberapa metodologi pendidikan Qurani seperti observasi yang dilanjutkan dengan praktek. Kemudian menyimpulkan inti pokok dari sebuah masalah dalam hal ini materi pembelajarannya, dan membuktikan kebenaran suatu ilmu melalui sebuah penelitian, merumuskan manfaat dan hikmah dari sebuah kejadian. Bisa pula berupa pendataan, rangkuman atas sebuah kegiatan pembelajaran yang dituangkan dalam bentuk worksheet.

Dengan demikian, hal di atas ada kaitannya dengan penelitian yang dilakukan dengan penggunaan metode pembelajaran Project Based Learning. Di mana seorang siswa menggunakan proyek sebagai tujuan dengan memfokuskan pada aktivitas siswa yang berupa mengumpulkan informasi dan pemanfaatannya untuk menghasilkan sesuatu yang bermanfaat bagi kehidupan diri sendiri dan orang lain.

Dalam proses mencapai tujuan pendidikan, adapun hal-hal yang harus diperhatikan diantaranya meliputi desain, strategi dan metode. Ketiga hal tersebut saling berhubungan satu dengan yang lain dan merupakan suatu kesatuan yang utuh atau tidak dapat dipisahkan. Desain mengandung arti perencanaan yaitu suatu proses yang dilakukan oleh guru dalam membimbing, membantu, dan mengarahkan peserta didik untuk memiliki pengalaman belajar serta mencapai tujuan pengajaran yang telah ditetapkan dengan langkah-langkah penyusunan materi pembelajaran, penggunaan media pengajaran, penggunaan metode dan pendekatan pengajaran, dan penilaian dalam suatu alokasi waktu yang akan dilaksanakan dalam waktu tertentu. Dan hal tersebut tertuang dalam pedoman pendidikan yaitu Kurikulum. Sehingga berdasarkan uraian tersebut, bahwa untuk dapat melaksanakan tugasnya secara profesional, seorang guru dituntut dapat memahami dan memiliki keterampilan yang memadai dalam mengembangkan berbagai model pembelajaran yang efektif, kreatif dan menyenangkan. 
Sesuai dengan pengamatan penulis khususnya di lingkungan MTs Al-Inayah Manado bahwa keaktifan belajar siswa pada mata pelajaran Al Qur'an Hadis termasuk kategori rendah, ini dapat dilihat dari aktivitas siswa yang cenderung pasif selama proses pembelajaran berlangsung.

Sesuai realita yang ada, banyaknya masalah yaitu siswa malas belajar pada mata pelajaran tertentu. Terkadang ini diakibatkan kurangnya minat dan motivasi pada siswa, baik dari metode yang digunakan guru dalam menyampaikan materi yang tidak efektif, cara guru yang mengajar monoton, kurangnya keaktifan siswa, kebanyakan juga guru hanya menjelaskan dan siswa mendengar serta diberikan pertanyaan siswa kurang paham dan tidak berani untuk menjawab. Dan ada pula siswa yang tidak tertarik pada pelajaran tersebut karena sulit untuk dipahami.

Mendapati hal tersebut, biasanya guru akan berusaha mengelakkannya dengan paksaan dan pengawasan. Siswa yang pasif tidak begitu saja dapat dipersalahkan, mungkin gurulah yang tidak berhasil memberikan motivasi yang membangkitkan keaktifan siswa.

Hal di atas merupakan kendala atau masalah dalam proses pembelajaran untuk mencapai tujuan belajar. Dalam kaitannya dengan hal tersebut, perlu adanya pendekatan pembelajaran yang mampu mengikat siswa untuk aktif dalam pembelajaran, membuat pembelajaran lebih relevan, menyenangkan, serta menyajikan pengalaman belajar yang membangkitkan motivasi untuk belajar. Sehingga sangat dibutuhkan keterampilan seorang guru dalam hal tersebut. Salah satu keterampilan yang dibutukan dalam memilih metode yang sesuai dengan bahan ajar/materi pokok dengan baik dan menyenangkan sehingga dapat mendorong siswa semangat belajar. Maka seorang guru harus mampu memberikan dengan baik dan segala kemampuan yang ada secara maksimal dalam menyampaikan materi harus bersifat mendidik. Bukan berarti seorang guru hanya sekedar mengajar saja hanya sebatas memberikan materi, akan tetapi siswa dapat merealisasikan ilmu yang diperoleh dalam kehidupan sehari-hari.

Dari permasalahan di atas, maka diperlukan model pembelajaran yang bervariasi dan inovatif agar siswa lebih aktif dalam pembelajaran dan juga akan menambah pengalaman kepada peserta didik sehingga akan terhindar dari rasa bosan dalam belajar. Banyak model pembelajaran yang dapat digunakan dalam proses pembelajaran tersebut, salah satu diantaranya yaitu model pembelajaran Project Based Learning. 


\section{Rumusan Masalah}

Berdasarkan latar belakang masalah yang telah diuraikan sebelumnya, maka rumusan masalah dalam penelitian ini adalah:

1. Bagaimana penerapan model pembelajaran di MTs AI-Inayah Manado?

2. Bagaimana implementasi model pembelajaran Project Based Learning untuk meningkatkan keaktifan belajar siswa di MTs Al-Inayah Manado?

3. Apa saja kendala dan bagaimana solusi dalam penerapan model pembelajaran Project Based Learning di MTs Al-Inayah Manado?

\section{Batasan Masalah}

Adapun batasan masalah dalam penelitian ini adalah seputar Implementasi Model Pembelajaran Project Based Learning untuk meningkatkan keaktifan belajar siswa pada mata pelajaran Al Qur'an Hadis dengan beberapa materi yang terdiri dari: (1) Pra tindakan yaitu hadis tentang tolong menolong dan mencintai anak yatim, (2) Siklus I tentang menerapkan hukum bacaan "ra" dan "lam" dalam surah Al-Humazah dan At-Takasur, dan (3) Siklus II yaitu memahami surah Al-Humazah dan At-Takatsur tentang menimbun harta di kelas VIII MTs Al-Inayah Manado.

\section{Kajian Teori}

\section{Model Pembelajaran Project Based Learning}

Istilah model pembelajaran mengarah pada suatu pendekatan pembelajaran tertentu termasuk tujuannya, sintaksnya, lingkungan, dan sistem pengelolaannya, sehingga model pembelajaran mempunyai makna yang luas dari pada pendekatan, strategi, metode atau prosedur (Sukardi, 2011).

Metode secara harfiah berarti cara. Dalam pemakaian yang umum, metode diartikan sebagai suatu cara atau prosedur yang dipakai untuk mencapai tujuan tertentu. Dalam kaitannya dengan pembelajaran, metode didefinisikan sebagai caracara menyajikan bahan pelajaran pada peserta didik untuk tercapainya tujuan yang telah ditetapkan. Dengan demikian model pembelajaran pada dasarnya merupakan bentuk pembelajaran yang tergambar dari awal sampai akhir yang disajikan secara khas oleh guru. Dengan kata lain, model pembelajaran merupakan bungkus atau bingkai dari penerapan suatu pendekatan, metode, dan teknik pembelajaran (Kumulasari, 2010). 
Model pembelajaran adalah suatu perencanaan atau suatu pola yang digunakan sebagai pedoman dalam merencanakan pembelajaran di kelas atau pembelajaran dalam tutorial dan untuk menentukan perangkat-perangkat pembelajaran termasuk buku-buku, film, computer, dan lain-lain. Setiap model pembelajaran mengarah kepada desain pembelajaran untuk membantu peserta didik sedemikian rupa sehingga tujuan pembelajaran tercapai (Dahlan, 1990).

Dalam pengembangan konsep model pembelajaran, maka guru harus bisa memastikan bahwa model mengajar atau pembelajaran itu harus mengandung suatu rasional yang didasarkan pada teori, berisi serangkaian langkah strategi yang dilakukan guru maupun siswa, didukung dengan sistem penunjang atau fasilitas pembelajaran, dan metode untuk mengevaluasi kemajuan belajar siswa. Ada banyak sekali teori yang menerangkan tentang macam-macam model pembelajaran, salah satunya model pembelajaran project based learning (Kurniasih \& Sani, 2015).

Berdasarkan penjelasan di atas, penulis dapat menyimpulkan bahwa model pembelajaran merupakan suatu perencanaan atau suatu pola yang digunakan guru dan siswa dalam menyampaikan materi pembelajaran untuk tercapainya tujuan yang telah ditetapkan.

Model Pembelajaran Berbasis Proyek adalah model pembelajaran yang menggunakan proyek/kegiatan sebagai tujuannya. Pembelajaran berbasis proyek memfokuskan pada aktivitas siswa yang berupa pengumpulan informasi dan pemanfaatannya untuk menghasilkan sesuatu yang bermanfaat bagi kehidupan siswa itu sendiri ataupun bagi orang lain, namun tetap terkait dengan KD dalam kurikulum (Kosasih, 2014).

Project Based Learing juga merupakan metode belajar yang menggunakan masalah sebagai langkah awal dalam mengumpulkan dan mengintegrasikan pengetahuan baru berdasarkan pengalamanya dalam beraktifitas secara nyata. Model pembelajaran Project Based Learing merupakan model pembelajaran yang memberikan kesempatan pada guru untuk mengelola pembelajaran di kelas dengan melibatkan kerja proyek (Wena, 2009).

1. Langkah-langkah Model Pembelajaran Project Based Learning.

Tahapan-tahapan pembelajaran Project Based Learning secara umum yakni sebagai berikut: 
a. Guru memaparkan topik yang akan dikaji, tujuan belajar, motivasi, dan kompetensi yang akan dicapai

b. Peserta didik mengidentifikasi permasalahan atau pertanyaan yang terkait dengan topik yang dikaji, pertanyaan juga dapat diajukan oleh guru

c. Kelompok membuat rencana proyek terkait dengan menyelesaikan permasalahan yang diidentifikasi

d. Kelompok membuat proyek atau karya dengan memahami konsep atau prinsip yang terkait dengan materi pelajaran

e. Guru atau sekolah memfasilitasi pameran atas pekerjaan/karya yang dihasilkan oleh peserta didik (Shoimin, 2014).

2. Kelebihan Model Pembelajaran Project Based Learning

Adapun kelebihan pada Model Pembelajaran Project Based Learning ini, antara lain sebagai berikut:

a. Increased motivation. Pembelajaran berbasis proyek dapat meningkatkan motivasi belajar siswa terbukti dari beberapa laporan peneliti tentang pembelajaran berbasis proyek yang menyatakan bahwa siswa sangat tekun, berusaha keras untuk menyelesaikan proyek, siswa merasa lebih bergairah dalam pembelajaran, dan keterlambatan dalam kehadiran sangat berkurang.

b. Increased problem-solving ability. Beberapa sumber mendeskripsikan bahwa lingkungan belajar pembelajaran berbasis proyek dapat meningkatkan kemampuan memecahkan masalah, membuat siswa lebih aktif dan berhasil memecahkan problem-problem yang bersifat kompleks.

c. Improved library research skills. Karena pembelajaran berbasis proyek mempersyaratkan siswa harus mampu secara cepat memperoleh informasi melalui sumber-sumber informasi, maka keterampilan siswa untuk mencari dan mendapatkan informasi akan meningkat.

d. Increased collaboration. Pentingnya kerja kelompok dalam proyek memerlukan siswa mengembangkan dan mempraktikan keterampilan komunikasi.

e. Increased resource-management skills. Pembelajaran berbais proyek yang diimplementasikan secara baik memberikan kepada siswa pembelajaran dan praktik dalam mengorganisasi proyek, dan membuat alokasi waktu dan sumber-sumber lain seperti perlengkapan untuk menyelesaikan tugas. 
3. Kekurangan Model Pembelajaran Project Based Learning

Kekurangan Model Pembelajaran Project Based Learning antara lain sebagai berikut:

a. Project Based Learning memerlukan pendalaman materi yang lebih baik sehingga siswa sampai pada pemikiran untuk bisa berkreasi dan mencipta sendiri suatu kegiatan ataupun karya, sebagai nurturant effect dari proses pembelajaran yang dilakoninya.

b. Project Based Learning memerlukan waktu yang cukup lapang karena berhadapan dengan proses kegiatan yang cukup kompleks.

c. Project Based Learning memerlukan tambahan sarana mungkin juga biaya.

d. Project Based Learning memerlukan proses pembelajaran yang penuh dinamika, antara lain ditandai oleh suasana ruang belajar tidak monoton (Kosasih, 2014).

Dalam setiap model pembelajaran mempunyai kelebihan dan kekurangan yang dihadapi oleh seorang guru saat menerapkan model pembelajaran. Hal di atas merupakan kelebihan dan kekurangan pada model pembelajaran Project Based Learning.

\section{Keaktifan Belajar}

Belajar merupakan proses aktif merangkai pengalaman menggunakan masalah-masalah nyata yang terdapat di lingkungannya untuk berlatih keterampilan-keterampilan yang spesifik. Dengan demikian belajar tidaklah bersifat pasif. Proses belajar harus berpusat pada siswa melalui berbagai aktivitas fisik (hands on) dan aktivitas mental (minds on). Guna membenahi sistem pembelajaran yang lebih bermakna, maka kegiatan belajar itu sendiri harus dirancang sedemikian rupa, sehingga seluruh siswa menjadi aktif dalam belajarnya, yang dapat merangsang daya cipta, rasa maupun karsa. Cara belajar yang aktif diasumsikan menjadi pangkal kesuksesan belajar. Bertolak dari asumsi tersebut, maka metode dan teknik belajar mengajar harus ditelaah kemampuannya untuk dapat mengaktifkan siswa sebagai subyek didik (Muhadjir, 2003).

Istilah belajar memiliki konsep dasar yang sama, yakni kegiatan yang mengubah keadaan seseorang menjadi lebih baik: pintar, menjadi orang besar, dan kondisi-kondisi positif lainnya. Belajar diartikan sebagai suatu peoses perubahan 
sikap dan tingkah laku setelah terjadinya interaksi dengan sumber belajar. Sumber belajar tersebut dapat berupa buku, lingkungan, guru, dan sejenisnya.

Adapun ciri-ciri yang menyertai proses terjadinya belajar, sekurangkurangnya ditandai oleh dua ciri: (1) adanya perubahan tingkah laku, (2) melalui suatu pengalaman atau adanya interaksi dengan sumber belajar.

Kata kunci perubahan tingkah laku penting mendapat perhatian karena dalam diri seseorang sangat mungkin terjadi berbagai perubahan tingkah laku dan tidak semua perubahan itu merupakan hasil belajar.

Salah satunya ciri perubahan yang bersifat aktif adalah ciri ini berkaitan dengan belajar sebagai kegiatan yang disengaja. Untuk memperoleh perilaku baru, seseorang harus bersengaja aktif untuk melakukan sejumlah aktivitas. Perubahan itu akan efektif terjadi pada diri seseorang jika dilalui dengan proses yang sungguhsungguh. Berbagai kegiatan harus ia lakukan. Dengan duduk manis di bangku sekolah dengan mendengar wejangan-wejangan guru, tidak akan terjadi perubahan diri yang efektif. Perubahan itu perlu disertai dengan aktivitas-aktivitas lainnya, seperti berdiskusi, membaca, melakukan pengamatan lapangan, ataupun melakukan praktik langsung dan mengerjakan sejumlah proyek (Kosasih, 2014).

Keaktifan berasal dari kata aktif yang artinya giat bekerja, giat berusaha, mampu bereaksi dan beraksi, sedangkan arti kata keaktifan adalah kesibukan atau kegiatan. Keaktifan siswa dalam kegiatan belajar tidak lain adalah untuk mengkonstruksi pengetahuan mereka sendiri. Mereka aktif membangun pemahaman atas persoalan atau segala sesuatu yang mereka hadapi dalam proses pembelajaran. Setiap orang yang belajar harus aktif sendiri, tanpa ada aktifitas proses pembelajaran tidak akan terjadi, sehingga keaktifan diartikan sebagai hal atau keadaan dimana siswa dapat aktif (Sardiman A.M., 2001). Segala pengetahuan harus diperoleh dengan pengamatan sendiri, pengalaman sendiri, penyelidikan sendiri, dengan bekerja sendiri dengan fasilitas yang diciptakan sendiri (Dimyati \& Mudjiono, 1999).

Terkait hal tersebut, ada tujuh dimensi implementasi pembelajaran siswa aktif yang meliputi:

1. Partisipasi siswa dalam menentukan tujuan kegiatan pembelajaran

2. Penekanan pada aspek afektif dalam pembelajaran 
3. Partisipasi siswa dalam melaksanakan kegiatan belajar mengajar terutama yang berbentuk interaksi antar siswa

4. Penerimaan guru terhadap perbuatan atau sumbangan siswa yang kurang relevan atau karena siswa berbuat kesalahan

5. Keeratan hubungan kelas sebagai kelompok

6. Kesempatan yang diberikan kepada siswa untuk mengambil keputusan yang penting dalam kegiatan sekolah

7. Jumlah waktu yang digunakan menangani masalah pribadi siswa, baik yang berhubungan ataupun tidak berhubungan dengan materi pelajaran (Wijaya, Djadjuri, \& Rusyan, 2000).

Salah satu penilaian proses pembelajaran adalah melihat sejauh mana keaktifan siswa dalam mengikuti proses belajar mengajar. Keaktifan adalah pada saat guru mengajar ia harus mengusahakan agar murid-muridnya aktif, jasmani maupun rohani. Keaktifan jasmani maupun rohani meliputi:

1. Keaktifan indera: Murid harus dirangsang agar dapat menggunakan alat inderanya sebaik mungkin.

2. Keaktifan akal: Akal anak-anak aktif atau diaktifkan untuk memecahkan masalah.

3. Kektifan ingatan: Pada waktu mengajar anak harus aktif menerima bahan pengajaran yang disampaikan oleh guru dan menyimpannya dalam otak.

4. Keaktifan emosi: Anak hendaklah senantiasa mencintai pelajarannya (Sriyono, 2009)

Berdasarkan pemaparan di atas peneliti dapat menyimpulkan bahwa keaktifan siswa dalam pembelajaran tergolong rendah jika: siswa tidak banyak bertanya, aktivitas siswa terbatas pada mendengarkan dan mencatat, siswa hadir di kelas dengan persiapan belajar yang tidak memadai, ribut jika diberi latihan/tugas, dan siswa hanya diam ketika ditanya sudah mengerti atau belum. Keaktifan belajar yang dimaksud yaitu keaktifan yang berfokus pada guru dan siswa. Di mana antara guru dan siswa ada hubungan antara satu dan lainnya dalam interaksi belajar sehingga dapat disebut sebagai pembelajaran aktif. Dalam proses pembelajaran di sekolah, untuk melibatkan siswa secara aktif dalam belajarnya, maka guru juga 
dituntut untuk aktif dalam mengajarnya, yakni suatu keseimbangan antara keaktifan belajarnya siswa dan keaktifan mengajarnya guru.

\section{Mata Pelajaran Al Qu'ran dan Hadis}

Al Qu'ran adalah bentuk masdar dari kata "Qara'a", Yaqra'u artinya “membaca”. Sehingga Al Qur'an menurut bahasa berarti “bacaan atau yang dibaca.

Allah swt berfirman dalam QS.AI-Qiyamah/75:17-18

"Sesungguhnya atas tanggungan Kamilah mengumpulkannya (Al Qur'an) di dadamu dan membuatmu pandai membaca. Maka bila Kami telah selesai membacakannya ikutilah bacaan tersebut" (Agama, 2012).

Al Qur'an menurut istilah (terminologi) juga mempunyai beberapa definisi, meskipun satu sama lain agak berbeda, namun ada segi-segi persamaannya. Diantara definisi Al Qur'an menurut istilah adalah sebagai berikut:

1. Al Qur'an adalah firman Allah swt yang merupakan mukjizat, yang diturunkan kepada Nabi dan Rasul terakhir dengan perantaraan Malaikat Jibril a.s yang terulis di dalam mushaf yang disampaikan kepada kita secara mutawatir yang diperintahkan membacanya, yang dimulai dengan surat Al-Fatihah dan ditutup dengan surat An-Nas.

2. Al Qur'an adalah lafal berbahasa Arab yang diturunkan kepada Nabi Muhammad saw, yang disampaikan kepada kita secara mutawatir, yang diperintahkan membacanya, yang menantang setiap orang (untuk menyusun) dengan (membuat) surat yang terpendek dari pada surat-surat yang ada didalamnya (Aminuddin \& Dkk, 2005).

Hadis atau al-Hadis menurut bahasa al-jadid yang artinya sesuatu yang barulawan dari al-Qadim (lama)-artinya yang berarti menunjukkan kepada waktu yang dekat atau waktu yang singkat. Hadis juga disebut dengan al-khabar, yang berarti berita, yaitu sesuatu yang dipercayakan dan dipindahkan dari seseorang kepada orang lain, sama maknanya dengan hadis. Sedangkan menurut istilah, para ahli memberikan definisi ( $t a$ 'rif) yang berbeda-beda sesuai dengan latar belakang disiplin ilmunya. Seperti pengertian hadis menurut ahli ushul akan berbeda dengan pengertian yang diberikan oleh ahli hadis.

Menurut ahli hadis, pengertian hadis ialah: segala perkataan Nabi, perbuatan, dan hal ihwalnya. Yang dimaksud dengan, “hal ihwal” ialah segala yang 
diriwayatkan dari Nabi saw. yang berkaitan dengan hikmah, karakteristik, sejak kelahiran, dan kebiasaan-kebiasaanya (Suparta, 2003).

Dalam lampiran Peraturan Menteri Agama Republik Indonesia Nomor 165 Tahun 2014 Tentang Kurikulum 2013 Mata Pelajaran Pendidikan Agama Islam dan Bahasa Arab pada Madrasah Bab IV Standar Isi Pendidikan sub A. Kelompok Mata Pelajaran, dan sub D. Tujuan dan Ruang Lingkup Mata Pelajaran Al Qur'an Hadis di Madrasah adalah salah satu nama mata pelajaran yang menekankan pada kemampuan siswa membaca dan menulis serta menghafalkan bagian dari teks Al Qur'an dan Hadis dengan benar, kemudian memahami maknanya secara tekstual dan kontekstual sekaligus merealisasikan/mengamalkan ajarannya dalam sistem kehidupan sehari-hari melalui keteladanan dan kebiasaan.

Dengan demikian, dapat disimpulkan bahwa mata pelajaran Al Qur'an Hadis adalah bagian mata pelajaran atau rumpun dari Pendidikan Agama Islam (PAI). Dengan tujuan untuk pemahaman, kemampuan, dan penghayatan terhadap isi yang terkandung dalam Al Qur'an dan Hadis sehingga dapat diwujudkan dalam perilaku sehari-hari sebagai perwujudan takwa kepada Allah swt.

\section{Hasil Penelitian}

\section{Hasil Pra Tindakan}

Kondisi pra tindakan sebelum melaksanakan penelitian, yaitu peneliti terlebih dahulu melakukan observasi di kelas yang akan diteliti yaitu kelas VIII MTs Al-Inayah Manado. Kegiatan pra tindakan digunakan untuk mengetahui kondisi kelas yang akan diteliti sebelum diberi tindakan dengan model pembelajaran Project Based Learning. Dari hasil pengamatan diperoleh beberapa informasi kondisi kelas sebelum diberi tindakan diantaranya diperoleh jadwal pelaksanaan pembelajaran pada kelas VIII MTs Al-Inayah Manado yang dilaksanakan setiap hari kamis selama 2 jam pelajaran mulai dari pukul 07.30 WITA sampai 08.50 WITA. Terdiri dari 20 siswa. Penugasan yang diberikan kepada siswa kelas VIII pada pra tindakan menggunakan gambar kerja dari guru mata pelajaran Al Qur'an Hadis yang telah dipakai sebelumnya.

Keaktifan belajar siswa kelas VIII MTs AI-Inayah Manado Semester II Tahun Pelajaran 2018/2019 khusunya pada mata pelajaran Al Qur'an Hadis masih sangat rendah atau dapat dikatakan motivasi siswa kurang. Hal ini disebabkan oleh guru yang masih menggunakan pendekatan tradisional dan monoton yaitu penggunaan 
metode ceramah, dan pemberian tugas menulis kepada para siswanya. Akibatnya para siswa menjadi tidak bersemangat dalam pembelajaran, jenuh, dan bosan. Proses pembelajaran dilaksanakan dengan urutan sebagai berikut:

1. Guru menjelaskan sedikit tentang materi

2. Siswa disuruh membaca buku teks dan merangkum sementara guru sibuk melaksanakan kegiatan lain, yang antara lain mengerjakan administrasi

3. Siswa disuruh mengerjakan soal-soal yang ada dalam buku paket siswa, dan selanjutnya hasil pekerjaan dikumpulkan untuk dinilai.

Tabel 1. Hasil Belajar Peserta Didik pada Pra Tindakan

\begin{tabular}{|c|c|c|}
\hline No. & Nama peserta didik & $\begin{array}{l}\text { Nilai Pra } \\
\text { Tindakan }\end{array}$ \\
\hline 1 & Adi D Lasari & 50 \\
\hline 2 & Akmal Hulio & 60 \\
\hline 3 & Alya Mohammad & 50 \\
\hline 4 & Djulia Madina & 60 \\
\hline 5 & Fajrin Pakaya & 60 \\
\hline 6 & Ismail Hasan & 60 \\
\hline 7 & Maryam Ali & 80 \\
\hline 8 & Muh. Arya Lahati & 50 \\
\hline 9 & Muh. Zidan Bendah & 50 \\
\hline 10 & Novianty S. Habibi & 60 \\
\hline 11 & Rahmadania Putri Djamil & 60 \\
\hline 12 & Rahmawati R. Laha & 50 \\
\hline 13 & Rani Amiri & 50 \\
\hline 14 & Rasya Syakila Pakaya & 80 \\
\hline 15 & Rivandi Laginda & 70 \\
\hline 16 & Rusdia Ramin & 50 \\
\hline 17 & Ruslan Hiola & 50 \\
\hline 18 & Siti M. Hasan & 50 \\
\hline
\end{tabular}




\begin{tabular}{lcc}
\hline 19 & Wahyudi Susanto & 40 \\
\hline 20 & Afla Dafa Markola & 40 \\
\hline & Jumlah & 1120 \\
\hline & Nilai Tertinggi & 80 \\
\hline & Nilai Terendah & 40 \\
\hline & Nilai Rata-rata & 56 \\
\hline & Ketuntasan Belajar & $10 \%$ \\
\hline
\end{tabular}

Pada hasil penelitian pra tindakan tabel 1, terlihat ada 2 orang siswa atau 10\% siswa yang mencapai kriteria ketuntasan belajar dengan nilai rata-rata 56, dengan jumlah nilai keseluruhan 1120. Maka hasil ini masih pada kategori sangat rendah.

Berdasarkan masalah yang ditemukan, maka peneliti merencanakan tindakan yaitu melalui pengamatan peneliti dalam menerapkan model pembelajaran Project Based Learning pada mata pelajaran Al Qur'an Hadis.

\section{Hasil Pelaksanaan Pembelajaran Siklus I}

Siklus I dilaksanakan dalam dua pertemuan, yaitu pada tanggal 15 Februari 2019 dan 22 Februari 2019 dilaksanakan setiap hari kamis selama 2 jam pelajaran mulai dari pukul 07.30 WITA sampai 08.50 WITA. Pada siklus I materi pembelajaran adalah menerapkan hukum bacaan "ra" dan "lam" dalam surah "Al-Humazah" dan "At-Takatsur".

Tabel. 2. Hasil Belajar Peserta Didik pada Siklus I

\begin{tabular}{clc}
\hline No. & Nama Peserta Didik & Nilai \\
siklus I
\end{tabular}




\begin{tabular}{|c|c|c|}
\hline 9 & Muh. Zidan Bendah & 50 \\
\hline 10 & Novianty S. Habibi & 70 \\
\hline 11 & Rahmadania Putri Djamil & 80 \\
\hline 12 & Rahmawati R. Laha & 60 \\
\hline 13 & Rani Amiri & 70 \\
\hline 14 & Rasya Syakila Pakaya & 90 \\
\hline 15 & Rivandi Laginda & 80 \\
\hline 16 & Rusdia Ramin & 60 \\
\hline 17 & Ruslan Hiola & 60 \\
\hline 18 & Siti M. Hasan & 70 \\
\hline 19 & Wahyudi Susanto & 50 \\
\hline 20 & Afla Dafa Markola & 50 \\
\hline & Jumlah & 1350 \\
\hline & Nilai Tertinggi & 90 \\
\hline & Nilai Terendah & 50 \\
\hline & Nilai Rata-rata & 67,5 \\
\hline & Ketuntasan Belajar & $25 \%$ \\
\hline
\end{tabular}

Berdasarkan tabel 2, hasil belajar pada siklus I dapat diketahui bahwa hanya 5 siswa dari 20 siswa dalam kelas yang mencapai ketuntasan belajar dengan daya serap $25 \%$ dengan nilai rata-rata 67,5 dengan jumlah nilai 1350 . Hal ini belum dapat dikatakan berhasil karena belum mencapai nilai rata-rata di atas 80. Oleh karena itu, pada siklus I dapat diketahui bahwa rendahnya hasil belajar siswa pada mata pelajaran Al Qur'an Hadis kelas VIII MTs AI-Inayah Manado. Maka peneliti melakukan tindakan II pada siklus selanjutnya.

Tabel 3. Hasil Observasi pada Siklus I

\begin{tabular}{ccccccccc}
\hline \multirow{2}{*}{ No } & \multirow{2}{*}{ Aspek penilaian } & \multicolumn{4}{c}{ Hasil pengamatan } & & Nilai \\
\cline { 3 - 6 } & SB & B & C & K & Jumlah & $\begin{array}{c}\text { rata- } \\
\text { rata }\end{array}$ \\
\hline 1 & Perhatian siswa & 10 & 5 & 5 & 0 & 65 & 3,25 \\
\hline 2 & Kedisiplinan siswa & 5 & 5 & 9 & 1 & 54 & 2,7 \\
\hline 3 & Keaktifan siswa & 3 & 7 & 8 & 1 & 50 & 2,5 \\
\hline 4 & Tanggungjawab siswa & 4 & 7 & 10 & 0 & 57 & 2,85 \\
\hline 5 & Kerjasama siswa & 4 & 11 & 5 & 0 & 59 & 2,95 \\
\hline & Jumlah & 26 & 35 & 32 & 2 & 285 & 2,85 \\
\hline
\end{tabular}


Keterangan:

$\mathrm{SB}($ Sangat Baik $)=4 \quad \mathrm{~B}($ Baik $)=3 \quad \mathrm{C}($ Cukup $)=2 \quad \mathrm{~K}($ Kurang $)=1$

Berdasarkan hasil lembar observasi tabel 3, mengenai aspek penilaian aktivitas siswa selama pembelajaran berlangsung dengan penerapan model pembelajaran Project Based Learning pada siklus I rata-rata adalah 2,85.

Tabel 4. Hasil Proyek Kelompok pada Siklus I

\begin{tabular}{ccc}
\hline No. Kelompok & Siklus & Nilai \\
\hline 1 & I & 55 \\
\hline 2 & I & 65 \\
\hline 3 & I & 60 \\
\hline 4 & I & 55 \\
\hline \multicolumn{3}{c}{ Jumlah } \\
\hline \multicolumn{2}{c}{ Scor Maksimal } & 435 \\
\hline \multicolumn{2}{c}{ Rata-Rata Presentase } & $58,75 \%$ \\
\hline
\end{tabular}

Berdasarkan tabel 4, hasil pengamatan secara kelompok menggunakan penilaian proyek yaitu rata-rata presentase adalah sebesar $58,75 \%$.

\section{Refleksi}

Refleksi dilakukan dengan cara diskusi antara peneliti dengan guru yang menerapkan model pembelajaran Project Based Learning melalui data yang diperoleh dari lembar observasi. Dari data tersebut diketahui bahwa pada pelaksanaan pembelajaran di kelas guru mengalami kesulitan dalam pengelolaan kelas, dikarenakan banyak siswa yang masih kebingungan dengan model pembelajaran yang dilakukan. Hal tersebut menjadi hambatan ketika pembelajaran berlangsung, karena siswa menjadi gaduh di kelas. Ketika guru menanyakan kepada siswa mengenai materi yang belum mereka pahami, hanya sebagian siswa yang bertanya. Ada beberapa siswa yang malu atau kurang percaya diri, sehingga mereka yang kurang paham, bertanya kepada temannya. Selain itu kendala lain dalam diskusi kelompok yaitu siswa masih mengerjakan soal secara mandiri sehingga guru harus membantu siswa untuk menumbuhkan kemampuan bekerja sama dengan kelompok. Dalam diskusi kelompok, masih banyak siswa yang asik dengan kegiatannya sendiri dan menciptakan keributan dalam kelompok dan kurang berinteraksi dengan teman satu kelompok. 


\section{Hasil Pembelajaran Siklus II}

Siklus II dilaksanakan dalam dua pertemuan, yaitu pada tanggal 28 Pebruari 2019 dan 07 Maret 2019 dilaksanakan setiap hari kamis selama 2 jam pelajaran mulai dari pukul 07.30 WITA sampai 08.50 WITA. Pada siklus II materi pembelajaran adalah memahami surah "Al-Humazah" dan "At-Takatsur" tentang menimbun harta. Berikut ini adalah langkah-langkah yang dilaksanakan pada siklus II:

\section{Perencanaan}

Berdasarkan data yang diperoleh dari siklus I maka diketahui bahwa hasil belajar siswa belum optimal. Oleh karena itu perlu dilakukan kembali pembelajaran dengan model pembelajaran Project Based Learning pada siklus II. Pada siklus II materi yang akan disampaikan adalah memahami surah "Al-Humazah" dan "AtTakatsur" tentang menimbun harta. Perencanaan pada siklus II tidak jauh berbeda dengan siklus I, disiapkan pula beberapa perlengkapan pembelajaran yaitu Rencana Pelaksanaan Pembelajaran (RPP), bahan ajar, dan lembar observasi. Perencanaan pembelajaran pada siklus II dilakukan dengan melihat adanya refleksi pada siklus I guna perbaikan pembelajaran.

\section{Pelaksanaan tindakan}

Dalam pelaksanaan pembelajaran dengan penerapan model pembelajaran Project Based Learning pada siklus II dibagi menjadi dua kali pertemuan dengan materi yang masih berhubungan pada siklus I, di mana dilanjutkan pada materi tentang memahami surah "Al-Humazah" dan "At-takatsur" tentang menimbun harta.

\section{Pengamatan}

Pengamatan dilakukan selama pembelajaran berlangsung dengan menerapkan model pembelajaran Project Based Learning dengan menggunakan lembar observasi yang telah disiapkan. Adapun diperoleh data hasil belajar siswa siklus II sebagai berikut:

Tabel 5. Hasil Belajar Peserta Didik pada Siklus II

\begin{tabular}{ccc}
\hline No. & Nama Peserta Didik & $\begin{array}{c}\text { Nilai } \\
\text { siklus II }\end{array}$ \\
\hline 1 & Adi D Lasari & 80 \\
\hline 2 & Akmal Hulio & 90 \\
\hline
\end{tabular}




\begin{tabular}{|c|c|c|}
\hline 3 & Alya Mohammad & 80 \\
\hline 4 & Djulia Madina & 90 \\
\hline 5 & Fajrin Pakaya & 80 \\
\hline 6 & Ismail Hasan & 80 \\
\hline 7 & Maryam Ali & 100 \\
\hline 8 & Muh. Arya Lahati & 70 \\
\hline 9 & Muh. Zidan Bendah & 70 \\
\hline 10 & Novianty S. Habibi & 80 \\
\hline 11 & Rahmadania Putri Djamil & 90 \\
\hline 12 & Rahmawati R. Laha & 80 \\
\hline 13 & Rani Amiri & 80 \\
\hline 14 & Rasya Syakila Pakaya & 100 \\
\hline 15 & Rivandi Laginda & 90 \\
\hline 16 & Rusdia Ramin & 80 \\
\hline 17 & Ruslan Hiola & 80 \\
\hline 18 & Siti M. Hasan & 80 \\
\hline 19 & Wahyudi Susanto & 70 \\
\hline 20 & Afla Dafa Markola & 70 \\
\hline & Jumlah & 1640 \\
\hline & Nilai Tertinggi & 100 \\
\hline & Nilai Terendah & 70 \\
\hline & Nilai Rata-rata & 82 \\
\hline & Ketuntasan Belajar & $80 \%$ \\
\hline
\end{tabular}

Berdasarkan tabel 5, hasil belajar pada siklus II terlihat sudah $80 \%$ siswa di dalam kelas mencapai ketuntasan belajar dengan daya serap $80 \%$ dengan nilai ratarata 82 dengan jumlah nilai total 1640. Dalam hal ini penerapan model pembelajaran model Project Based Learning ini sudah berhasil meningkatkan keaktifan belajar siswa karena telah mencapai kriteria ketuntasan yaitu $80 \%$ kategori sangat baik, maka peneliti tidak melanjutkan pada siklus berikutnya.

Tabel 6. Hasil Observasi pada Siklus II

\begin{tabular}{lllllllll}
\hline \multirow{2}{*}{ No } & \multirow{2}{*}{ Aspek Penilaian } & \multicolumn{4}{c}{ Hasil Pengamatan } & & Nilai \\
\cline { 3 - 6 } & SB & B & C & K & Jumlah & $\begin{array}{c}\text { rata- } \\
\text { rata }\end{array}$ \\
\hline 1 & Perhatian siswa & 12 & 8 & - & - & 72 & 3,6 \\
\hline
\end{tabular}




\begin{tabular}{clcccccc}
2 & Kedisiplinan siswa & 7 & 7 & 6 & - & 61 & 3,05 \\
\hline 3 & Keaktifan siswa & 5 & 10 & 5 & - & 60 & 3 \\
\hline 4 & Tanggungjawab siswa & 6 & 11 & 4 & - & 65 & 3,25 \\
\hline 5 & Kerjasama siswa & 6 & 12 & 2 & - & 64 & 3,2 \\
\hline & Jumlah & 36 & 48 & 17 & - & 322 & 3,22 \\
\hline
\end{tabular}

Keterangan:

$\mathrm{SB}($ Sangat Baik $)=4 \quad B($ Baik $)=3 \quad C($ Cukup $)=2 \quad K($ Kurang $)=1$

Berdasarkan hasil lembar observasi tabel 6, mengenai aspek penilaian aktivitas siswa selama pembelajaran berlangsung dengan penerapan model pembelajaran Project Based Learning pada siklus II mengalami peningkatan yaitu menunjukkan bahwa hasil yang dicapai dengan nilai rata-rata adalah 3,22.

Tabel 7. Hasil Proyek Kelompok pada Siklus II

\begin{tabular}{|c|c|c|}
\hline No. Kelompok & SIKLUS & NILAI \\
\hline 1 & II & 70 \\
\hline 2 & II & 80 \\
\hline 3 & II & 75 \\
\hline 4 & II & 70 \\
\hline \multicolumn{2}{|c|}{ Jumlah } & 295 \\
\hline \multicolumn{2}{|c|}{ Scor Maksimal } & 400 \\
\hline \multicolumn{2}{|c|}{ Rata-Rata Presentase } & $73,75 \%$ \\
\hline
\end{tabular}

Berdasarkan tabel 7, hasil pengamatan secara kelompok menggunakan penilaian proyek mengalami peningkatan yaitu rata-rata presentase adalah sebesar $73,75 \%$.

4. Refleksi

Berdasarkan hasil pengamatan selama kegiatan pembelajaran pada siklus II, tampak bahwa proses kegiatan pembelajaran berjalan dengan lancar dan lebih baik jika dibandingkan pada siklus I. Siswa lebih mandiri dan percaya diri dalam mengerjakan soal tes. Selain itu perhatian siswa pada saat guru menerangkan juga sudah baik.Siswa menjadi aktif bertanya kepada guru ketika mengalami kesulitan ataupun menjawab pertanyaan dari guru. Kerjasama dan interaksi siswa dalam kelompok sudah tampak dan siswa juga sudah percaya diri ketika mempresentasikan hasil diskusi kelompok. 


\section{Pembahasan Hasil Penelitian}

Berdasarkan penelitian yang telah dilakukan tentang "implementasi model pembelajaran Project Based Learning untuk meningkatkan keaktifan belajar siswa pada mata pelajaran Al Qur'an Hadis di MTs Al-Inayah Manado”. Sebagaimana hasil observasi awal di kelas VIII yang dijadikan sebagai objek penelitian, ada beberapa masalah yang ditemukan dalam proses pembelajaran berlangsung pada mata pelajaran Al Qur'an Hadis, yaitu kurangnya keaktifan siswa belajar. Hal ini bisa disebabkan dari dalam diri siswa itu sendiri ataupun dari luar yaitu lingkungan belajar. Sesuai observasi awal, disebabkan kurangnya minat dan motivasi siswa yaitu metode yang digunakan dalam menyampaikan materi tidak efektif, cara guru mengajar yang monoton, kurangnya keaktifan siswa, guru hanya menjelaskan dan siswa mendengar serta diberikan pertanyaan siswa kurang paham dan tidak berani untuk menjawab.

Kurangnya keaktifan siswa juga memberikan pengaruh pada pemahaman atau pengetahuan siswa mengenai materi yang telah disampaikan. Sehingga dari hasil diskusi antara peneliti dan guru mata pelajaran AI Qur'an Hadis dapat diperoleh data hasil belajar siswa yang tidak memenuhi ketuntasan belajar $80 \%$.

Kemudian peneliti dan guru bekerjasama dalam mengatasi masalah tersebut. Banyaknya model pembelajaran yang efektif, maka peneliti menyarankan dengan menggunakan model pembelajaran Project Based Learning. Model pembelajaran Project Based Learning adalah model pembelajaran yang menggunakan proyek/kegiatan sebagai tujuannya. Pembelajaran berbasis proyek memfokuskan pada aktivitas siswa yang berupa pengumpulan informasi dan pemanfaatannya untuk menghasilkan sesuatu yang bermanfaat bagi kehidupan siswa itu sendiri ataupun bagi orang lain, namun tetap terkait dengan Kompetensi Dasar dalam kurikulum.

Adapun dalam pelaksanaannya, penelitian ini terdiri dari dua siklus. Siklus I dilakukan sebanyak dua kali pertemuan dan siklus II dilakukan sebanyak dua kali pertemuan, di mana materi yang diberikan berbeda pada tiap siklusnya. Materi yang diberikan pada siklus I yaitu menerapkan hukum bacaan "ra" dan "lam" dalam surah "Al-Humazah" dan "At-Takatsur", sedangkan pada siklus II yaitu memahami surah "Al-Humazah" dan "At-Takatsur" tentang "menimbun harta”.

Pada siklus I pelaksanaan pembelajaran di kelas guru mengalami kesulitan dalam pengelolaan kelas, dikarenakan banyak siswa yang masih kebingungan 
dengan model pembelajaran yang dilakukan. Hal tersebut menjadi hambatan ketika pembelajaran berlangsung, karena siswa menjadi gaduh di kelas. Ketika guru menanyakan kepada siswa mengenai materi yang belum mereka pahami, hanya sebagian siswa yang bertanya. Ada beberapa siswa yang malu atau kurang percaya diri, sehingga mereka yang kurang paham, bertanya kepada temannya. Selain itu kendala lain dalam diskusi kelompok yaitu siswa masih mengerjakan soal secara mandiri sehingga guru harus membantu siswa untuk menumbuhkan kemampuan bekerja sama dengan kelompok. Dalam diskusi kelompok, masih banyak siswa yang asik dengan kegiatannya sendiri dan menciptakan keributan dalam kelompok dan kurang berinteraksi dengan teman satu kelompok.

Sedangkan pada siklus II, tampak bahwa proses kegiatan pembelajaran berjalan dengan lancar dan lebih baik jika dibandingkan pada siklus I. Siswa lebih mandiri dan percaya diri dalam mengerjakan soal tes. Selain itu perhatian siswa pada saat guru menerangkan juga sudah baik. Siswa menjadi aktif bertanya kepada guru ketika mengalami kesulitan ataupun menjawab pertanyaan dari guru. Kerjasama dan interaksi siswa dalam kelompok sudah tampak dan siswa juga sudah percaya diri ketika mempresentasikan hasil diskusi kelompok.

Dari penelitian yang telah dilakukan, dengan penerapan model pembelajaran Project Based Learning baik pada siklus I maupun siklus II menunjukkan adanya peningkatan hasil belajar sesuai dengan hasil lembar observasi siswa kelas VIII MTs Al-Inayah Manado.

Perbandingan hasil belajar pada pra tindakan, siklus I dan siklus II dapat dilihat pada tabel dibawah ini:

Tabel 8. Peningkatan Hasil Belajar

\begin{tabular}{cc}
\hline Siklus & Hasil Belajar \\
\hline Pra Tindakan & $10 \%$ \\
\hline I & $25 \%$ \\
\hline II & $80 \%$ \\
\hline Peningkatan & $15 \%$ dan $55 \%=70 \%$ \\
\hline
\end{tabular}


Data pada tabel 8 tersebut menunjukkan bahwa hasil belajar siswa mengalami peningkatan $70 \%$ dari pra tindakan ke siklus I dan ke siklus II. Pada pra tindakan hasil belajar siswa mencapai $10 \%$, hal ini termasuk belum termasuk kriteria ketuntasan yakni kategori sangat rendah. Kemudian pada siklus I yang telah di berikan tindakan menggunakan model pembelajaran Project Based Learning hasil belajar siswa meningkat menjadi $25 \%$, namun hal ini juga masih terdapat siswa yang belum masuk kategori ketuntasan belajar dan masih dikatakan rendah, sedangkan pada siklus II meningkat menjadi $80 \%$ sehingga siswa dapat dikatakan telah memenuhi kriteria ketuntasan belajar yakni $80 \%$ bahkan sangat baik. Hasil belajar siswa dari pra tindakan ke siklus I mengalami peningkatan $15 \%$ dan dari siklus I ke siklus II mengalami peningkatan sebesar $55 \%$.

Tabel 9. Peningkatan Hasil Observasi

\begin{tabular}{ll}
\hline Siklus & Hasil Observasi \\
\hline I & 2,85 \\
\hline II & 3,22 \\
\hline Peningkatan & 0,37 \\
\hline
\end{tabular}

Data pada tabel 9 di atas menunjukkan hasil observasi siswa selama proses pembelajaran berlangsung mengalami kenaikan dari siklus I ke siklus II. Pada siklus I hasil observasi mencapai rata-rata 2,85, sedangkan pada siklus II meningkat menjadi 3,22. Hasil observasi dari siklus I ke siklus II mengalami peningkatan sebesar 0,37. Meskipun peningkatannya kecil dari segi nominalnya tapi cukup menggembirakan karena pemahaman dan keseriusan siswa sangat baik dan dalam mengikuti pelajaran, oleh karena itu sudah ada perubahan yang terjadi dari siklus I ke siklus II.

Tabel 10. Peningkatan Hasil Proyek Kelompok

\begin{tabular}{ll}
\hline Siklus & Hasil Proyek \\
\hline I & $58,75 \%$ \\
\hline II & $73,75 \%$ \\
\hline Peningkatan & $15 \%$ \\
\hline
\end{tabular}

Perbandingan peningkatan hasil proyek kelompok dapat dilihat pada tabel 4.10 mengalami kenaikan dari siklus I ke siklus II. Pada siklus I rata-rata presentase 
mencapai 58,75\%. Sedangkan pada siklus II meningkat menjadi 73,75\%. Dan dari siklus I ke siklus II mengalami peningkatan sebesar $15 \%$.

Dilihat dari penjelasan di atas bahwa memang sesuai dengan data yang diperoleh dalam penelitian ini model pembelajaran Project Based Learning dapat meningkatkan keaktifan belajar siswa pada mata pelajaran Al Qur'an Hadis kelas VIII MTs Al-Inayah Manado.

\section{Kesimpulan}

Berdasarkan uraian di atas maka dapat disimpulkan sebagai berikut:

1. Hasil pengamatan awal diperoleh kondisi kelas yang akan diteliti sebelum diberi tindakan dengan model pembelajaran Project Based Learning, yaitu keaktifan belajar siswa di MTs Al-Inayah Manado Semester II Tahun Pelajaran 2018/2019 khusunya pada mata pelajaran Al Qur'an Hadis masih sangat rendah dan motivasi siswa yang kurang. Hal ini disebabkan masih menggunakan pendekatan tradisional dan monoton yaitu penggunaan metode ceramah, dan pemberian tugas menulis kepada para siswanya. Akibatnya para siswa menjadi tidak bersemangat dalam pembelajaran, jenuh, dan bosan. Sehingga sebagian besar siswa tidak mencapai nilai kriteria ketuntasan belajar. Pada hasil penelitian pratindakan terlihat hanya 2 atau 10\% siswa yang mencapai kriteria ketuntasan belajar dengan nilai rata-rata 56, dengan jumlah nilai 1120. Maka hasil ini masih pada kategori sangat rendah.

2. Setelah diterapkannya model pembelajaran Project Based Learning pada mata pelajaran Al Qur'an Hadis, keaktifan siswa sudah mulai baik dari observasi awal yang hanya menggunakan metode ceramah, di mana siswa sudah lebih aktif bertanya, menjawab dan menjelaskan materi yang telah disampaikan. Hal ini dapat diketahui dari hasil belajar siswa pada akhir pelajaran, hasil lembar observasi, dan hasil proyek yang dilakukan perkelompok. Adapun hal tersebut diperoleh peningkatan pada tiap siklusnya, pada siklus I rata-rata persentase hasil belajar sebesar $25 \%$ dan meningkat pada siklus II yaitu sebesar $80 \%$. Pada siklus I hasil observasi mencapai rata-rata 2,85 dan pada siklus II meningkat dengan rata-rata 3,22. Pada siklus I hasil proyek kelompok rata-rata presentase mencapai $58,75 \%$ dan pada siklus II meningkat menjadi $73,75 \%$. Dengan demikian pada siklus II telah berhasil meningkatkan keaktifan dan telah mencapai kriteria ketuntasan belajar yakni $80 \%$ sangat baik. 
Adapun kendala dan solusi dalam menerapkan model pembelajaran Project Based Learning pada mata pelajaran Al Qur'an Hadis, yaitu model pembelajaran Project Based Learning ( $\mathrm{PjBL}$ ) belum pernah di terapkan dalam pembelajaran di kelas, dan biasanya guru hanya menggunakan metode ceramah dan metode demonstrasi. Pada siklus I pada pelaksanaan pembelajaran di kelas peneliti mengalami kesulitan dalam pengelolaan kelas. Banyak siswa yang masih kebingungan dengan model pembelajaran yang dilakukan, sehingga menyebabkan siswa menjadi gaduh di kelas. Ketika guru bertanya masih ada yang kurang paham, dan dalam diskusi kelompok masih banyak siswa yang asik dengan kegiatannya sendiri, menciptakan keributan dalam kelompok dan kurang berinteraksi dengan teman satu kelompok. Kemudian untuk memperbaiki kendala di atas, peneliti dan guru merencanakan langkah-langkah yang akan dilaksanakan pada siklus II, yaitu guru menjelaskan kembali model pembelajaran yang digunakan sehingga siswa tidak merasa kebingungan dan tidak menciptakan kegaduhan, guru memotivasi siswa untuk aktif dalam bertanya sehingga siswa benar-benar paham apa yang dipelajari, dan guru memotivasi siswa untuk lebih berpartisipasi aktif dan bekerjasama dalam kelompok

\section{Referensi}

Agama, K. (2012). Al-Qur'an dan Terjemahnya. Jakarta: PT. Sinergi Pustaka Indonesia. Aminuddin, \& Dkk. (2005). Pendidikan Agama Islam untuk Perguruan Tinggi. Bogor: Ghalia Indonesia.

Bahasa, T. P. K. P. (2005). Kamus Besar Bahasa Indonesia. Jakarta: Balai Pustaka.

Basyir, H., Haidar, H., Muslim, M., \& Isma'il, A. A. (n.d.). At Tafsirul Muyassar. Saudi Arabia: Percetakan Al Qur'an Raja Fahd.

Dahlan. (1990). Model-Model Mengajar. Bandung.

Dimyati, \& Mudjiono. (1999). Belajar dan Pembelajaran. Jakarta: Rineka Cipta.

Kosasih. (2014). Strategi Belajar dan Pembelajaran Implementasi Kurikulum 2013. Bandung: Yrama Widya.

Kumulasari, K. (2010). Pembelajaran Kontekstual Konseptual dan Aplikasi. Bandung: PT. Refika Aditama.

Kurniasih, I., \& Sani, B. (2015). Ragam Pengembangan Model Pembelajaran untuk Peningkatan Profesionalitas Guru. Jakarta: Kata Pena.

Muhadjir, N. (2003). Ilmu Pendidikan dan Perubahan Sosial. Yogyakarta: Rake Sarasin. 
Sardiman A.M. (2001). Interaksi dan Motivasi Belajar Mengajar. Jakarta: RajaGrafindo Persada.

Shoimin, A. (2014). 68 Model Pembelajaran yang Inovatif dalam Kurikulum 2013. Yogyakarta: Ar-Ruzz Media.

Sriyono. (2009). Teknik Belajar Mengajar dalam CBSA. Jakarta: Rineka Cipta.

Sukardi, I. (2011). Model dan Metode Pembelajaran Modern Suatu Pengantar. Palembang: Tunas Gemilang Pres.

Suparta, M. (2003). Ilmu Hadis. Jakarta: RajaGrafindo Persada.

Wena. (2009). Strategi Pembelajaran Inovatif Kontemporer. Jakarta: Bumi Aksara.

Wijaya, Djadjuri, \& Rusyan. (2000). Pembaharuan dalam Pendidikan dan Pengajaran. Bandung: PT Remaja Rosda Karya. 